\title{
BEBERAPA FAKTOR YANG MEMPENGARUHI PENYUSUNAN ANGGARAN PENDAPATAN DAN BELANJA SEKOLAH (APBS) BERBASIS KINERJA (Studi Empiris di SMK Negeri Se-Kota Madiun)
}

\author{
Hariyadi \\ Magister Akuntansi \\ Fakultas Ekonomi dan Bisnis - Universitas Sebelas Maret Surakarta
}

\begin{abstract}
ABSTRAK
Penelitian ini bertujuan untuk mengetahui pengaruh kepemimpinan, komitmen dari seluruh komponen organisasi, penyempurnaan sistem administrasi, sumber daya yang cukup, penghargaan (reward) yang jelas, dan sanksi (punishment) yang tegas terhadap Anggaran Pendapatan dan Belanja Sekolah (APBS) berbasis kinerja. Penelitian ini menggunakan data primer dengan menyebarkan angket kepada responden. Sebagai populasi data dalam penelitian ini adalah SMK/SMA/MA Negeri dan swasta se-Kota Madiun, dan sebagai sampel datanya adalah SMK Negeri se-Kota Madiun sebanyak 5 (lima) sekolah. Banyaknya responden 75 orang meliputi kepala sekolah, wakil kepala sekolah, ketua program keahlian, kepala tata usaha, guru dan staf tata usaha, serta pengurus komite sekolah.Metode penelitian yang digunakan adalah regresi linier berganda (Multiple Linear Regression Analysis). Berdasarkan penelitian dengan memasukkan data dari hasil kuisioner menyatakan bahwa secara simultan kepemimpinan, komitmen dari seluruh komponen organisasi, sumber daya yang cukup, penghargaan (reward) yang jelassanksi (punishment) yang tegas secara signifikan berpengaruh terhadap penyusunan APBS berbasis kinerja.Namun secara parsial faktor-faktor yang berpengaruh positif dan signifikan terhadap penyusunan APBS berbasis kinerja adalah komitmen dari seluruh komponen organisasi, penyempurnaan sistem administrasi, dan penghargaan (reward) yang jelas.Sedangkan kepemimpinan, sumber daya yang cukup dan sanksi (punishment) yang tegas tidak berpengaruh terhadap penyusunan APBS berbasis kinerja.
\end{abstract}

Kata Kunci : kepemimpinan, komitmen dari seluruh komponen organisasi, penyempurnaan sistem administrasi, sumber daya yang cukup, penghargaan (reward), sanksi (punishment), APBS berbasis kinerja.

\section{PENDAHULUAN}

Sekolah, sebagai lembaga/institusi, mempunyai satu atau lebih tujuan. Untuk mencapai tujuan tersebut, perlu disusun rencana dan langkah bagaimana cara mencapai tujuan tersebut. Pada umumnya tujuan sekolah dipaparkan dalam bentuk Visi dan Misi Sekolah. Cara pencapaiannya dilakukan melalui berbagai perencanaan dan program kegiatan yang dituangkan dalam Rencana Pengembangan Sekolah (RPS). Umumnya sekolah cenderung statis. Mereka mulai bergerak setelah ada masalah yang muncul. Perencanaan dilakukan tidak hanya untuk mengatasi masalah yang sedang dihadapi, tetapi juga untuk perencanaan ke depan dalam hal peningkatan kinerja sekolah atau untuk mengantisipasi perubahan dan tuntutan jaman.

Perencanaan program dirinci secara terukur dan realistis dalam jenis-jenis kegiatan konkret yang mampu dilaksanakan. Perencanaan sebaiknya tidak dibuat terlalu muluk, tidak berpijak pada kondisi yang sesungguhnya, dan kurang melihat inti permasalahan. Hal seperti ini perlu diidentifikasi terlebih dahulu, dianalisis penyebabnya, dan dicarikan alternatif pemecahannya. Alternatif mengatasi permasalahan yang dijadikan pilihan 
prioritas atas kegiatan haruslah dicari terlebih dahulu, disusun anggarannya, kemudian dicarikan kekurangan dananya (yang masih diperlukan).

Sistem penganggaran seperti ini disebut juga dengan Anggaran Berbasis Kinerja (ABK). Penyusunan anggaran berbasis kinerja secara resmi diperkenalkan oleh Komisi Hoover (Cothran 1993; Lynch 1995) dengan penekanan pada upaya untuk menghindari rekayasa reformasi sosial yaitu untuk meniadakan transformasi mekanistik anggaran. (Bouckaert 1994; Boorsma dan Mol 1995) dalam penelitiannya menjelaskan bahwa tujuan penganggaran akan lebih baik dicapai melalui penerapan seperangkat teknik yang mampu untuk menggantikan rekening debit-kredit neraca dan mencerminkan sejumlah pembiayaan.

Anggaran Berbasis Kinerja (ABK) merupakan metode penganggaran bagi manajemen untuk mengaitkan setiap biaya yang dituangkan dalam kegiatan-kegiatan dengan manfaat yang dihasilkan. Manfaat tersebut didiskripsikan pada seperangkat tujuan dan dituangkan dalam target kinerja pada setiap unit kerja. Alasan dari penyusunan anggaran berbasis kinerja terutama untuk penguatan kontrol dan evaluasi proses hasil anggaran, melalui pemberdayaan parlemen dan kantor audit (Peters dan Savoie 1996) dan kurangnya pengamatan terhadap kapasitas organisasi publik untuk mengidentifikasi berbagai kekurangan diri mereka (kurangnya data yang dapat diandalkan, kemampuan belajar yang rendah, komunikasi yang buruk dengan organisasi dan pemangku kepentingan) yang sering menyebabkan re-alokasi anggaran yang ada setelah menghubungkannya dengan beberapa "tujuan" dan"hasil" (Walters 1994).

Penerapan Performance Budgeting-Based (PBB) disebut juga dengan Anggaran Berbasis Kinerja $(\mathrm{ABK})$ di sektor publik mengalami beberapa tantangan, antara lain: Pertama, manajemen publik menyederhanakan peran serta stakeholder dalam proses penganggaran dimana peran administrasi publik dalam sistem pemerintahan terpusat (Denhardt danDenhardt2000), sedangkan (Vigoda 2002) mengusulkan bahwa warga negara hendaknya diperlakukan sebagai mitra sejajar daripada sebagai pelanggan pasif dalam proses pemerintahan. Kedua, manajemen publik mengabaikan nilai-nilai demokrasi konstitusional (Kliman dan Fisher1995; Piotrowski dan Rosenbloom 2002), sehingga banyak upaya legislatif dan yudikatif dikhususkan untuk membuat administrasi publik lebih transparan, perwakilan, partisipatif, dan pelindung hak-hak individu. Ketiga, Performance Budgeting-Based (PBB) tidak memiliki prinsip-prinsip operasional alokasi anggaran untuk layaknya nama, siapa yang menentukan nilai "seberapa baik" atau "baik?". Dalam penganggaran publik, bukan tugas yang mudah untuk mengatur hasil target antara berbagai pemangku kepentingan. Bahkan jika target hasil yang ditetapkan, maka akan sulit untuk menentukan siapa (atau program apa) yang bertanggung jawab untuk hasil tersebut (Stiefel etal.1999). Keempat, ambiguitas alokasi anggaran diperparah oleh adanya alokasi anggaran tahunan yang tetap, terutama di tingkat federal (McNab dan Melese 2003; Kliman dan Fisher1995).

Sekolah-sekolah di lingkungan pemerintah Kota Madiun dalam menyusun Rencana Kerja dan Anggaran Sekolah (RKAS), belum sepenuhnya berdasarkan penganggaran berbasis kinerja, hal ini tampak pada pengisian pengukuran indikator kinerja pada RKA yang disusun belum menggambarkan adanya kaitan yang erat antara tujuan dengan proses pengelolaan pencapaian (management for results), perencanaan kinerja dan target kinerja. Hal ini jelas bahwa penerapan terhadap Permendiknas Nomor 19 tahun 2007 tentang Standar Pengelolaan Pendidikan belum sepenuhnya dilakukan oleh sekolah-sekolah di lingkungan Pemerintah Kota Madiun. Penyusunan anggaran berbasis kinerja juga telah dituangkan dalam Keputusan Menteri Dalam Negeri Nomor 29 tahun 2002 pasal 19 ayat (2) usulam program, kegiatan dan anggaran berdasarkan prinsip-prinsip anggaran kinerja. 


\section{KAJIAN TEORI DAN PENGEMBANGAN HIPOTESIS}

\section{Pengertian Anggaran}

Menurut (Wildavsky dan Caiden 1975) anggaran adalah : (a) catatan masa lalu, (b) rencana masa depan, (c) mekanisme pengalokasian sumber daya, (d) metode untuk pertumbuhan, (e) alat penyaluran pendapatan, (f) mekanisme untuk negosiasi, (g) harapanaspirasi-strategi organisasi, (h) satu bentuk kekuatan kontrol, dan (i) alat atau jaringan komunikasi. Menurut Undang-undang Nomor 17 Tahun 2003, anggaran adalah alat akuntabilitas, manajemen, dan kebijakan ekonomi. Sebagai instrumen kebijakan ekonomi, anggaran berfungsi untuk mewujudkan pertumbuhan dan stabilitas perekonomian serta pemerataan pendapatan dalam rangka mencapai tujuan bernegara.

Penganggaran berbasis kinerja (performance based budgeting) diantaranya menjadi jawaban untuk digunakan sebagai alat pengukuran dan pertanggung-jawaban kinerja pemerintah. Penganggaran berbasis kinerja merupakan metode penganggaran bagi manajemen untuk mengaitkan setiap pendanaan yang dituangkan dalam kegiatan-kegiatan dengan keluaran (output) dan hasil yang diharapkan (outcome) termasuk efisiensi dalam pencapaian hasil dari keluaran tersebut. Keluaran dan hasil tersebut dituangkan dalam target kinerja pada setiap unit kerja. Sedangkan bagaimana tujuan itu dicapai, dituangkan dalam program yang diikuti dengan pembiayaan pada setiap tingkat pencapaian tujuan. Anggaran berbasis kinerja merupakan sistem penganggaran yang memberikan fokus pada fungsi dan kegiatan pada suatu unit organisasi, dimana setiap kegiatan yang ada tersebut harus dapat diukur kinerjanya. Definisi lain pada buku Modul Overview Keuangan Negara oleh Departemen Keuangan (2008), anggaran berbasis kinerja merupakan metode penganggaran bagi manajemen untuk mengaitkan setiap pendanaan yang dituangkan dalam kegiatan-kegiatan dengan keluaran dan hasil yang diharapkan termasuk efisiensi dalam pencapaian hasil dari keluaran tersebut.

\section{PENGEMBANGAN HIPOTESIS}

Secara teoritis, kepemimpinan (leadership) merupakan hal yang sangat penting dalam manajerial, karena kepemimpinan yang baik maka proses manajemen akan berjalan dengan baik dan pegawai akan bergairah dalam melakukan tugasnya (Widiyantora 2005). Faktor kepemimpinan memainkan peranan yang sangat penting dalam keseluruhan upaya untuk meningkatkan kinerja, baik pada tingkat kelompok maupun dalam tingkat organisasi. Dikatakan demikian karena kinerja tidak hanya menyoroti pada sudut tenaga pelaksana yang pada umumnya bersifat teknis akan tetapi juga di kelompok kerja dan manajerial (Widiyantora 2005). Berdasarkan uraian di atas, maka dapat dirumuskan hipotesis sebagai berikut:

$\mathrm{H}_{1}$ : Faktor kepeminpinan berpengaruh positif terhadap penyusunan Anggaran Pendapatan dan Belanja Sekolah (APBS) berbasis kinerja.

Menurut (Kunwaviyah dan Machmud 2010), komitmen organisasi merupakan tingkat sampai sejauh mana seorang karyawan memihak pada suatu organisasi tertentu dan tujuan-tujuannya, serta berniat untuk mempertahankan keanggotaannya dalam organisasi tersebut. (Melkers 1998) memberikan pengertian komitmen organisasi sebagai seseorang yang memiliki nilai dan keinginan untuk tetap tinggal menjadi anggota organisasi. Komitmen organisasi menunjukkan keyakinan dan dukungan serta loyalitas seseorang terhadap nilai dan sasaran yang ingin dicapai organisasi (Mowday et al. 1979). Komitmen organisasi yang kuat akan menyebabkan individu berusaha mencapai tujuan organisasi, berpikiran positif dan berusaha untuk berbuat yang terbaik bagi organisasinya. Berdasarkan uraian tersebut dapat dirumuskan hipotesis sebagai berikut:

$\mathrm{H}_{2}$ : Faktor komitmen dari seluruh komponen organisasi berpengaruh positif terhadap penyusunan Anggaran Pendapatan dan Belanja Sekolah (APBS) berbasis kinerja. 
(Bastian 2006), penyusunan anggaran berbasis kinerja membutuhkan suatu sistem administrasi publik yang telah ditata dengan baik, konsisten dan terstruktur sehingga kinerja anggaran dapat dicapai berdasarkan ukuran-ukuran yang telah ditetapkan. Demikian pula menurut (Tjokroamidjojo 1985) dalam (Sinaga 2008) bahwa reformasi administrasi perlu ditujukan pada penyempurnaan administrasi untuk mendukung pembangunan daerah. Penyempurnaan administrasi secara berkelanjutan berupa penyiapan instrumen pengukuran anggaran berbasis kinerja secara terus menerus melalui penyempurnaan instrumen pengukuran anggaran berbasis kinerja yang sudah ada yaitu Standar Pelayanan Minimal, Standar Analisis Belanja, Target Kinerja dan Standar Biaya merupakan faktor penting dalam keberhasilan penyusunan APBD berbasis kinerja. Berdasarkan uraian tersebut dapat dirumuskan hipotesis sebagai berikut:

$\mathrm{H}_{3}$ : Faktor penyempurnaan sistem administrasi berpengaruh positif terhadap penyusunan Anggaran Pendapatan dan Belanja Sekolah (APBS) berbasis kinerja.

Sumber daya yang cukup, yaitu upaya penyediaan sarana dan prasarana peningkatan kualitas implemantasi anggaran berbasis kinerja (Sembiring 2009). Sumber daya yang cukup disini adalah termasuk uang, waktu dan orang yang akan melakukan proses pengganggaran berbasis kinerja. Ada dua elemen mendasar yang berkaitan dengan pengembangan sumber daya manusia yaitu tingkat pendidikan dan keterampilan yang dimiliki oleh pekerja (Kusdayah 2008). Untuk peningkatan kualitas sumber daya manusia dapat dilakukan dengan pelatihan-pelatihan yang sesuai dengan kebutuhan yang diperlukan, sehingga sumber daya manusia yang tersedia mampu untuk menjalankan tugas pokoknya dalam meningkatkan pelayanan organisasi terhadap kebutuhan publik. Sarana dan prasarana penunjangpun terus diperbaiki dan dilengkapi sehingga ketika sumber daya manusia yang telah ada siap, sarana penunjangpun telah ada sehingga dapat dipergunakan untuk mewujudkan penerapan anggaran berbasis kinerja.

Berdasarkan uraian tersebut dapat dirumuskan hipotesis sebagai berikut:

$\mathrm{H}_{4}$ : Faktor sumber daya yang cukup berpengaruh positif terhadap penyusunan Anggaran Pendapatan dan Belanja Sekolah (APBS) berbasis kinerja.

Pemberian penghargaan (reward) merupakan hal yang penting untuk mencapai keberhasilan penyusunana APBS berbasis kinerja.Sesuai dengan teori yang dikemukakan oleh (Gibson et al. 2000) dalam (Wibowo 2007) yang menyatakan bahwa tujuan utama program penghargaan (reward) adalah untuk memotivasi pegawai untuk mencapai kinerja. Demikian pula menurut (Mulyadi 1998) dalam (Mardiyah 2005) bahwa sistem reward dan pengakuan atas kinerja karyawan merupakan sarana untuk mengarahkan perilaku karyawan ke perilaku yang dihargai dan diakui organisasi. Berdasarkan uraian tersebut dapat dirumuskan hipotesis sebagai berikut:

$\mathrm{H}_{5}$ : Faktor penghargaan (reward) berpengaruh positif terhadap penyusunan Anggaran Pendapatan dan Belanja Sekolah (APBS) berbasis kinerja.

Penerapan sanksi (punishment) adalah penting dalam keberhasilan penyusunan APBS berbasis kinerja. (Skinner 1983) dalam (Wahyuningsih 2009) yang mengungkapkan bahwa perilaku manusia dibentuk oleh rangkaian penguatan dan hukuman (punishment) yang diterimanya dari lingkungan.Demikian pula menurut (Subagyo 2006) dalam (Wahyuningsih 2009), sosialisasi pemberlakuan peraturan-peraturan pokok organisasi kepada anggota organisasi belumlah cukup walaupun dilakukan secara terus menerus jika tidak disertai adanya mekanisme pemberian sanksi yang tegas dan dilaksanakan sebagaimana mestinya.Berdasarkan uraian tersebut dapat dirumuskan hipotesis sebagai berikut: $\mathrm{H}_{6}$ : Faktor sanksi (punishment) sebagai faktor-faktor yang berpengaruh positif terhadap penyusunan Anggaran Pendapatan dan Belanja Sekolah (APBS) berbasis kinerja. 


\section{METODE PENELITIAN}

Jenis penelitian yang digunakan dalam penelitian ini adalah penelitian deskriptif dan penelitian empiris. Populasi penelitian ini adalah seluruh stakeholder penyusun Anggaran Pendapatan dan Belanja Sekolah pada SMK/SMA/MA se-Kota Madiun sebanyak 45 sekolah yang terdiri dari 720 orang. Teknik penentuan sampel penelitian adalah purposive sampling. Adapun kriteria pemilihan sampel dalam penelitian ini adalah orang-orang yang langsung terlibat dalam penyusunan anggaran pendapatan dan belanja sekolah (APBS) pada SMK Negeri se-Kota Madiun, yang terdiri dari 80 orang yaitu kepala SMK sebanyak 5 orang, wakil kepala sekolah sebanyak 20 orang, kepala tata usaha sebanyak 5 orang, ketua kompetensi keahlian sebanyak 20 orang, guru dan staf tata usaha sebanyak 20 orang, pengurus komite sekolah sebanyak 10 orang.

\section{DEFINISI OPERASIONAL DAN PENGUKURAN VARIABEL}

Definisi operasional dan pengukuran dari setiap variabel dapat digambarkan sebagai berikut:

1. Variabel kepemimpinan $(K p)$, diukur dengan menggunakan instrumen terdiri dari 7 (tujuh) item pertanyaan untuk menentukan kemampuan kepala sekolah dalam melaksanakan tugas pokok dan fungsi organisasi untuk keberhasilan melakukan visi, misi, tujuan, sasaran sesuai dengan Renstra Sekolah.

2. Variabel komitmen dari seluruh komponen organisasi (Kmt, diukur dengan menggunakan instrumen terdiri dari 9 (sembilan) item pertanyaan untuk menentukan adanya kesepakatan antara kepala sekolah dengan seluruh komponen organisasi untuk keberhasilan melakukan visi, misi, tujuan, sasaran sesuai dengan Renstra Sekolah.

3. Variabel penyempurnaan sistem administrasi (Sad),diukur dengan menggunakan instrumen terdiri dari 6 (enam) item pertanyaan untuk menentukan adanya penyiapan instrumen pengukuran anggaran berbasis kinerja secara terus menerus.

4. Variabel sumber daya yang cukup $(S d)$, diukur dengan menggunakan instrumen terdiri dari 9 (sembilan) item pertanyaan untuk menentukan tersedianya sumber daya dalam rangka peningkatan implementasi anggaran berbasis kinerja.

5. Variabel Penghargaan (reward) yang jelas (Rew), diukur dengan menggunakan instrumen terdiri dari 3 (tiga) item pertanyaan untuk menentukan adanya penerapan secara adil ddan konsisten atas keberhasilan dalam implementasi anggaran berbasis kinerja.

6. Variabel Sanksi (punishment) yang tegas (Pun), diukur dengan menggunakan instrumen terdiri dari 3 (tiga) item pertanyaan untuk menentukan adanya penerapan hukuman (punishment) secara adil dan konsisten atas ketidak-berhasilan dalam implementasi anggaran berbasis kinerja.

7. Variabel dependen APBS berbasis kinerja $(A P B S)$, diukur dengan menggunakan instrumen terdiri dari 7 (tujuh) item pertanyaan untuk menentukan tersusunnya anggaran pendapatan dan belanja sekolah yang berbasis kinerja dari suatu anggaran yang mengutamakan upaya pencapaian hasil kerja atau output dan perencanaaan alokasi biaya.

\section{TEKNIK ANALISIS DATA}

Model dan teknik analisis data dalam penelitian ini menggunakan pendekatan regresi linier berganda (Multiple Linear Regression Analysis). Menurut (Sugiyanto 2004) "analisis regresi linier berganda digunakan untuk menganalisis pengaruh lebih dari satu variabel 
independen terhadap variabel dependen". Model analisis regresi linier berganda dalam penelitian ini dapat dirumuskan sebagai berikut :

\section{$\mathrm{APBS}=\mathbf{a}+\mathrm{b}_{1} \mathrm{Kp}+\mathrm{b}_{2} \mathrm{Kmt}+\mathrm{b}_{3} \mathrm{Sad}+\mathrm{b}_{4} \mathrm{Sd}+\mathrm{b}_{5} \mathrm{Rew}+\mathrm{b}_{6} \mathrm{Pun}+\mathrm{e}$}

Keterangan :

APBS = Anggaran Pendapatan dan Belanja Sekolah Berbasis Kinerja.

$a \quad=\quad$ Konstansta.

$b_{1},-b_{6}=$ Koefisien regresi.

$K p=$ Kepemimpinan,

Kmt $=$ Komitmen dari seluruh komponen organisasi

$\mathrm{Sad} \quad=$ Penyempurnaan sistem administrasi

Sd $\quad=\quad$ Sumber daya yang cukup

Rew $\quad=\quad$ Penghargaan $($ reward $)$ yang jelas

Pun $\quad=$ Hukuman sanksi (punishment) yang tegas

$e \quad=\quad$ Error term.

\section{HASIL DAN PEMBAHASAN}

Untuk menguji hipotesis bahwa kepemimpinan, komitmen dari seluruh komponen organisasi, penyempurnaan sistem administrasi, sumber daya yang cukup, penghargaan (reward) yang jelas dan sanksi (punishment) yang tegas berpengaruh terhadap APBS berbasis kinerja secara simultan dengan uji $\mathrm{F}$ dan uji parsial dengan uji t.

1. Pengujian Hipotesis dengan Uji F

Pengaruh variabel independen secara simultan terhadap variabel dependen dianalisis dengan menggunakan uji $\mathrm{F}$, yaitu dengan memperhatikan signifikansi nilai $\mathrm{F}$ pada output perhitungan dengan tingkat alpha 5\%. Jika nilai signifikansi uji $\mathrm{F}$ lebih kecil dari 5\% maka terdapat pengaruh antara semua variabel independen terhadap variabel dependen.

Hasil pengujian uji F pada penelitian ini dapat dilihat pada tabel di bawah ini:

Tabel 1 Hasil Uji F

\begin{tabular}{llccccc}
\hline \multicolumn{7}{c}{ ANOVA $^{\mathbf{b}}$} \\
\hline Model & Sum of Squares & Df & Mean Square & F & Sig. \\
\hline 1 & Regression & 10.358 & 6 & 1.726 & 69.369 & $.000^{\mathrm{a}}$ \\
& Residual & 1.692 & 68 & .025 & & \\
& Total & 12.050 & 74 & & & \\
\hline
\end{tabular}

a. Predictors: (Constant), Pun, Sd, Kp, Rew, Sad, Kmt

b. Dependent Variable: APBS

Sumber: Hasil Penelitian tahun 2015 (data diolah)

Pada hasil uji regresi dalam penelitian ini, diketahui nilai uji $\mathrm{F}$ sebesar 69,369 dengan signifikansi 0,000.Dimana disyaratkan nilai signifikansi $\mathrm{F}$ lebih kecil dari 5\%.Dengan demikian dapat disimpulkan bahwa semua variabel independen dalam penelitian ini secara bersama-sama (simultan) berpengaruh terhadap APBS berbasis kinerja $(A P B S)$. Hal tersebut berarti jika kepemimpinan $(K p)$, komitmen dari seluruh komponen organisasi $(K m t)$, penyempurnaan sistem administrasi $(S a d)$, sumber daya yang cukup $(S d)$, penghargaan (reward) yang jelas (Rew) serta sanksi (punishment) yang tegas (Pun) secara bersama-sama mengalami kenaikan, maka akan berdampak pada kenaikan APBS berbasis kinerja $(A P B S)$, sebaliknya jika keenam variabel tersebut 
secara bersama-sama mengalami penurunan maka akan berdampak pada penurunan APBS berbasis kinerja $(A P B S)$.

2. Pengujian Hipotesis dengan Uji $t$

Setelah dilakukan pengujian asumsi klasik, pembahasan akan dilanjutkan dengan pengujian hipotesis, dengan memperhatikan nilai $t$ hitung dari hasil regresi tersebut untuk mengetahui pengaruh variabel independen secara parsial terhadap variabel dependen dengan tingkat kepercayaan $95 \%$ atau pada alpha $5 \%$. Dengan syarat apabila nilai variabel independen signifikan terhadap variabel dependen, maka terdapat pengaruh antara variabel independen terhadap variabel dependen, sedangkan apabila tidak signifikan maka tidak terdapat pengaruh antara variabel independen terhadap variabel dependen.

Tabel 2

Nilai $t$ hitung

\begin{tabular}{lcccc}
\hline \multicolumn{1}{c}{ Variabel } & $t$ hitung & Signifikansi & $+/-$ & Keputusan \\
\hline Kp & 1,413 & 0,162 & + & Hipotesis $\left(\mathrm{H}_{1}\right)$ ditolak \\
Kmt & 2,204 & 0,031 & + & Hipotesis $\left(\mathrm{H}_{1}\right)$ diterima \\
Sad & 10,171 & 0,000 & + & Hipotesis $\left(\mathrm{H}_{1}\right)$ diterima \\
Sd & 0,427 & 0,671 & + & Hipotesis $\left(\mathrm{H}_{1}\right)$ ditolak \\
Rew & 3,685 & 0,000 & + & Hipotesis $\left(\mathrm{H}_{1}\right)$ diterima \\
Pun & 0,492 & 0,624 & + & Hipotesis $\left(\mathrm{H}_{1}\right)$ ditolak \\
\hline
\end{tabular}

Sumber: Hasil Penelitian tahun 2015 (data diolah)

Dari tabel di atas, diketahui nilai siginifikan dari masing-masing variabel independen. Dari nilai tersebut untuk variabel komitmen dari seluruh komponen organisasi $(\mathrm{Kmt})$, penyempurnaan sistem administrasi $(\mathrm{Sad})$, dan penghargaan (reward) yang jelas (Rew) dibawah 0,05 , maka $\mathrm{H}_{1}$ diterima, dengan kata lain komitmen dari seluruh komponen organisasi (Kmt), penyempurnaan sistem administrasi (Sad), dan penghargaan (reward) yang jelas (Rew) berpengaruh positif terhadap APBS berbasis kinerja. Sedangkan kepemimpinan $(K p)$, sumber daya yang cukup $(S d)$, dan sanksi (punishment) yang tegas (Pun) diatas 0,05 , maka $\mathrm{H}_{1}$ ditolak, artinya kepemimpinan $(K p)$, sumber daya yang cukup $(S d)$, dan sanksi (punishment) yang tegas (Pun) tidak berpengaruh terhadap APBS berbasis kinerja.

\section{HASIL PERSAMAAN REGRESI}

Untuk mempermudah pembacaan hasil dan interpretasi analisis regresi maka digunakan bentuk persamaan.Persamaan atau model tersebut berisi konstanta dan koefisien-koefisien regresi yang didapat dari hasil pengolahan data yang telah dilakukan sebelumnya. Persamaan regresi yang telah dirumuskan kemudian dengan bantuan program SPSS 17.0 dilakukan pengolahan data yang dapat dilihat pada tabel berikut:

Tabel 3

Koefisian Regresi

\begin{tabular}{llccc}
\hline & & \multicolumn{2}{c}{ Unstandardized Coefficients } & Standardized Coefficients \\
\cline { 3 - 5 } Model & B & Std. Error & Beta \\
\hline 1 & (Constant) & .455 & .336 & .174 \\
& Kp & .208 & .147 & .290 \\
& Kmt & .348 & .158 & .715 \\
& Sad & .586 & .058 & .023 \\
& Sd & .021 & .049 & .245 \\
& Rew & .168 & .046 & .033 \\
\hline
\end{tabular}

a. Dependent Variable: APBS

Sumber: Hasil Penelitian tahun 2015 (data diolah) 


\section{$A P B S=0,455+0,208 K p+0,348 K m t+0,586 S a d+0,021 S d+0,168 R e w+0,039 P u n$}

Dari persamaan tersebut dapat diartikan: 1) jika variabel bebas dalam model diasumsikan sama dengan nol, secara rata-rata variabel diluar model tetap akan meningkatkan APBS berbasis kinerja sebesar 0,455 satuan; 2) variabel kepemimpinan $(K p)$ berpengaruh positif terhadap APBS berbasis kinerja dengan peningkatan sebesar sebesar 0,208 satuan; 3) variabel komitmen dari seluruh komponen organisasi (Kmt) berpengaruh positif terhadap APBS berbasis kinerja dengan peningkatan sebesar 0,348 satuan; 4) variabel penyempurnaan sistem administrasi ( $\mathrm{Sad}$ ) berpengaruh positif terhadap APBS berbasis kinerja peningkatan sebesar 0,586 satuan; 5) variabel sumber daya yang cukup $(S d)$ berpengaruh positif terhadap APBS berbasis kinerja dengan peningkatan sebesar 0,021 satuan; 6) variabel penghargaan (reward) yang jelas (Rew) berpengaruh positif terhadap APBS berbasis kinerja dengan peningkatan sebesar sebesar 0,168 satuan; dan 7) variabel sanksi (punishment) yang tegas (Pun) berpengaruh positif terhadap APBS berbasis kinerja dengan peningkatan sebesar 0,039 satuan.

\section{ANALISIS KOEFISIEN DETERMINASI $\left(\boldsymbol{R}^{2}\right)$}

Besarnya koefisien determinasi $\left(R^{2}\right)$ yang disesuaikan (adjusted) sebesar 0,860 (86\%). Hal ini dapat dikatakan bahwa sebesar $86 \%$ variasi variabel dependen yaitu APBS berbasis kinerja $(A P B S)$ pada model dapat diterangkan oleh variabel bebas yaitu variabel kepemimpinan $(K p)$, komitmen dari seluruh komponen organisasi $(K m t)$, penyempurnaan sistem administrasi $(S a d)$, sumber daya yang cukup $(S d)$, penghargaan (reward) yang jelas (Rew) serta sanksi (punishment) yang tegas (Pun), sedangkan sisanya sebesar 14\% dipengaruhi oleh variabel lain di luar model. Hasil analisis koefisien determinasi dapat dilihat pada tabel berikut ini:

\section{Tabel 4}

Hasil Analisis Koefisien Determinasi

\begin{tabular}{|c|c|c|c|c|c|}
\hline Model & $\mathrm{R}$ & R Square & $\begin{array}{l}\text { Adjusted R } \\
\text { Square }\end{array}$ & $\begin{array}{l}\text { Std. Error of the } \\
\text { Estimate }\end{array}$ & Durbin-Watson \\
\hline 1 & $.927^{\mathrm{a}}$ & .860 & .847 & .15775 & 1.834 \\
\hline
\end{tabular}

\section{PEMBAHASAN PENELITIAN}

Pada pengujian hipotesis berdasarkan hasil perhitungan dapat dikatakan bahwa komitmen dari seluruh komponen organisasi, penyempurnaan sistem administrasi, dan penghargaan (reward) yang jelas berpengaruh terhadap APBS berbasis kinerja baik secara simultan maupun parsial telah terbukti $\left(\mathrm{H}_{1}\right.$ diterima), sedangkan kepemimpinan, sumber daya yang cukup, dan sanksi (punishment) yang tegas secara parsial tidak signifikan berpengaruh terhadap APBS berbasis kinerja $\left(\mathrm{H}_{1}\right.$ ditolak). Dari hasil ini dapat dilihat bahwa semakin baik komitmen dari seluruh komponen organisasi, penyempurnaan sistem administrasi, dan penghargaan (reward) yang jelas tentunya memberikan kontribusi yang baik terhadap peningkatan APBS berbasis kinerja.

Pengaruh kepemimpinan terhadap APBS berbasis kinerja adalah positif dan tidak signifikan. Positif terlihat dari koefisien regresi komitmen dari kepemimpinan sebesar 0,208 dan tidak signifikan karena tingkat kesignifikansinya lebih dari 0,05 yaitu 0,162 . Pengaruh positif menunjukkan bahwa kepemimpinan kepala sekolah berpengaruh searah 
dengan APBS berbasis kinerja atau dengan kata lain kepemimpinan kepala sekolah yang baik/tinggi akan berpengaruh baik terhadap APBS berbasis kinerja.

Pengaruh komitmen dari seluruh komponen organisasi terhadap APBS berbasis kinerja adalah positif dan signifikan. Positif terlihat dari koefisien regresi komitmen dari seluruh komponen organisasi sebesar 0,348 dan signifikan karena nilai kesignifikansinya menunjukkan angka 0,031 kurang dari 0,05. Pengaruh positif menunjukkan bahwa pengaruh komitmen dari seluruh komponen organisasi adalah searah dengan APBS berbasis kinerja atau dengan kata lain komitmen dari seluruh komponen organisasi yang baik/tinggi akan berpengaruh terhadap APBS berbasis kinerja yang baik/tinggi.

Pengaruh penyempurnaan sistem administrasi terhadap APBD berbasis kinerja adalah positif dan signifikan. Positif terlihat dari koefisien regresi penyempurnaan sistem administrasi sebesar 0,586 dan signifikan karena nilai kesignifikansinya menunjukkan angka 0,000 kurang dari 0,05.Pengaruh positif menunjukkan bahwa pengaruh penyempurnaan sistem administrasi adalah searah dengan APBS berbasis kinerja atau dengan kata lain penyempurnaan sistem administrasi yang baik/tinggi akan berpengaruh terhadap APBS berbasis kinerja yang baik/tinggi.

Pengaruh sumber daya yang cukup terhadap APBS berbasis kinerja adalah positif dan tidak signifikan. Positif terlihat dari koefisien regresi sumber daya yang cukup sebesar 0,021 dan tidak signifikan karena nilai kesignikansinya menunjukkan angka 0,671 lebih dari 0,05.Pengaruh positif menunjukkan bahwa pengaruh sumber daya yang cukup adalah searah dengan APBS berbasis kinerja atau dengan kata lain sumber daya yang cukup yang baik/tinggi akan berpengaruh terhadap APBS berbasis kinerja yang baik/tinggi.

Pengaruh penghargaan (reward) yang jelas terhadap APBS berbasis kinerja adalah positif dan signifikan. Positif terlihat dari koefisien regresi penghargaan (reward) yang jelas sebesar 0,168 dan signifikan karena nilai kesignifikansinya menunjukkan angka 0,000 krang dari 0,05. Pengaruh positif menunjukkan bahwa pengaruh penghargaan (reward) yang jelas adalah searah dengan APBS berbasis kinerja atau dengan kata lain penghargaan (reward) yang jelas dan baik/tinggi akan berpengaruh terhadap APBS berbasis kinerja yang baik/tinggi.

Pengaruh sanksi yang tegas terhadap APBS berbasis kinerja adalah positif dan tidak signifikan.Positif terlihat dari koefisien regresi sanksi yang tegas sebesar 0,039 dan signifikan karena nilai kesigniikansinya menunjukkan angka 0,624.Pengaruh positif menunjukkan bahwa pengaruh sanksi yang tegas adalah searah dengan APBS berbasis kinerja atau dengan kata lain sanksi yang tegas yang baik/tinggi akan berpengaruh terhadap APBD berbasis kinerja yang baik/tinggi.

\section{KESIMPULAN DAN SARAN}

Berdasarkan pembahasan hasil penelitian, maka ditarik kesimpulan sebagai berikut:

1. Secara simultan kepemimpinan $(K p)$, komitmen dari seluruh komponen organisasi $(K m t)$, penyempurnaan sistem administrasi $(S a d)$, sumber daya yang cukup $(S d)$, penghargaan (reward) yang jelas (Rew) serta sanksi (punishment) yang tegas (Pun) berpengaruh terhadap Anggaran Pendapatan dan Belanja Sekolah (APBS) berbasis kinerja $(A P B S)$, hal ini sejalan dengan penelitian sebelumnya bahwa pemberlakukan anggaran berbasis kinerja secara simultan berpengaruh terhadap kinerja keuangan Pemerintah Daerah Kabupaten Deli Serdang (Lubis 2010).

2. Secara parsial komitmen dari seluruh komponen organisasi $(K m t)$, penyempurnaan sistem administrasi ( $\mathrm{Sad}$ ), dan penghargaan (reward) yang jelas (Rew) masingmasing berpengaruh positif terhadap APBS berbasis kinerja $(A P B S)$, sedangkan kepemimpinan $(K p)$, sumber daya yang cukup $(S d)$ dan sanksi (punishment) yang 
tegas (Pun) tidak berpengaruh terhadap APBS berbasis kinerja. Dari beberapa faktor tersebut yang paling banyak berpengaruh terhadap penyusunan APBS berbasis kinerja adalah penyempurnaan sistem administrasi.

3. Bahwa penelitian ini dapat dinyatakan cukup memadai dimana $86 \%$ variabel dependen yaitu APBS berbasis kinerja (APBS) dipengaruhi oleh variabel independen kepemimpinan $(K p)$, komitmen dari seluruh komponen organisasi $(K m t)$, penyempurnaan sistem administrasi $(S a d)$, sumber daya yang cukup $(S d)$, penghargaan (reward) yang jelas (Rew) serta sanksi (punishment) yang tegas (Pun) ) dan sisanya $14 \%$ dipengaruhi variable lain diluar model.

Saran penelitian selanjutnya untuk penyempurnaan penerapan APBS berbasis kinerja disampaikan beberapa saran yaitu:

1. Peneliti berikutnya agar mengambil data dari data sekunder (realisasi capaian kinerja program dan kegiatan).

2. Peneliti berikutnya memperluas lokasi penelitian dibeberapa sekolah tidak hanya pada SMK Negeri, tetapi diacak untuk SMK/SMA negeri dan swasta agar dapat mewakilinya.

3. Penelitian berikutnya untuk menambah variabel lain untuk penyempurnaan penyusunan Anggaran Berbasis Kinerja seperti: pemahaman terhadap visi misi sekolah, tujuan sekolah, adanya target kinerja, pengukuran kinerja, standar pelayanan minimal, analisis standar belanja, dan standar harga.

\section{DAFTAR PUSTAKA}

Ateik, Hotman 2005, Analisis Peranan Bappeda dalam Menyusun APBD berdasarkan Sistem Anggaran Berbasis Kinerja Menuju Kepemerintahan yang Baik di Kabupaten Tulang Bawang Lampung, Tesis, Medan

Bastian, Indra. 2006. Akuntansi Sektor Publik. Jakarta: Erlangga.

Bouckaert, G. 1994. The History of the Productivity Movement, in M. Holzer and A. Halachmi (Eds,),Competent Government: Theory and Practice: The Best of Public Productivity and Management Review, 1985-1993.Burke: Chatelaine Press.

Boorsma, P. and Mol, N. 1995.The Dutch Public Financial Revolution. In W. Kickert and F. van Vught (Eds.) Public Policy and Administration Sciences in the Netherlands. London: Prentice- Hall/Harvester Vheatsheaf.

BPKP. 2000. Pengukuran Kinerja: Suatu Tinjauan Pada Instansi Pemerintah. Jakarta.

BPKP. 2005. Pedoman Penyusunan Anggaran Berbasis Kinerja (Revisi). Jakarta.

Cothran, D. A. 1993. "Entrepreneurial Budgeting: An Emerging Reform?"Public Administration Review, 53.

Denhardt, J. and M. Denhardt. 2000. Estimation of benchmark performance standards: An application to public school performance. Journal of Accounting and Economics 23 (2).

Ditjen Perbendaharaan Departemen Keuangan R.I. 2008. Modul Pengelolaan Keuangan Negara. Jakarta.

Erlina dan Mulyani, Sri. 2007. Metodologi Penelitian Bisnis Untuk Akuntansi dan Manajemen, USU press, Medan

Ghozali, Ikhsan dan Arfan, Imam. 2007. Metodologi Penelitian Untuk Akuntansi Dan Manajemen.PT. Madju Medan Cipta. Medan.

Indriantoro dan Supomo. 1999.Metodologi Penelitian Bisnis Untuk Akuntansi dan Manajemen, Edisi Pertama, BPFE Yogyakarta. 
John F. Due. 2000. Government Finance: An Economic Analysis, The Journal Finance Vol 19, No. 3.

Kementerian Negara Perencanaan Pembangunan Nasional/Bappenas.2006. Manajemen Yang Berorientasi Peningkatan Kinerja Instansi Pemerintah. Jakarta.

Kliman, and T.Fisher.1995. Performance Information and Budgeting in Historical and Comparative Perspective, Journal of Accounting and Economics 23.

Kliman, Albert J., and Louis Fisher. 1995a. "Budget Reform Proposals in the NPR Report."' Public Budgeting \& Finance 15(1).

Kliman, Albert J., and Louis Fisher. 1995b. "Response by Leonard, Cook, and McNeil to NPR Piece.' Public Budgeting \& Finance 15(1).

Kusdayah, Rahmawati Ike 2008.Manajemen Sumber Daya Manusia. Yogyakarta: CV. Andi Offset.

Kuncoro, Mudrajad. 2003. Metode Riset Untuk Bisnis Dan Ekonomi. Erlangga. Jakarta.

Kunwaviyah, dan Machmud. 2010. Peran Variabel Komitmen Organisasi dan Inovasi pada Hubungan Penganggaran dan Kinerja. Jurnal Akuntansi dan Auditing, Vol 7 No 1.

Lembaga Administrasi Negara. 2003. Perbaikan Pedoman Penyusunan Pelaporan Akuntabilitas Kinerja Instansi Pemerintah.Keputusan Kepala LAN Nomor 239/IX/6/8/2003, Jakarta.

Lembaga Administrasi Negara. 2004. Sistem Akuntabilitas Kinerja Instansi Pemerintah, (Edisi Kedua). LAN RI, Jakarta.

Lubis, Ade Fatma, et.al. 2010. Aplikasi SPSS (Statistical Product and Service Solutions) untuk Penyusunan Skripsi dan Tesis.USU press, Medan.

Lynch, T.D. 1995. Public budgeting in America, 4th ed., New Jersey: Prentice Hall.

McNab, Robert M., and Francois Melese. 2003. "Implementing the GPRA: Examining the Prospects for Performance Budgeting in the Federal Government." Public Budgeting \& Finance 23.

Mardiyah. 2005. Pengaruh Sistem Pengukuran, Sistem Reward dan Profit Center Terhadap Hubungan Antara TQM dan Kinerja Manajerial. SNA VIII. September, Solo.

Nugroho, Bambang. 2006. Reward and Punishment. Bulletin Cipta Karya, Departemen Pekerjaan Umum, Edisi No.6/IV/Juni.

Peters, G.B. and Savoie D. J. 1996. Managing incoherence: the coordination and empowerment conundrum, Public Administration Review, 56 (3), 281-290

Peraturan Menteri Dalam Negeri Nomor 13. 2006. Pedoman Pengelolaan Keuangan Daerah.

Peraturan Menteri Dalam Negeri Nomor 6. 2007. Petunjuk Teknis Penyusunan dan Penetapan Standar Pelayanan Minimal.

Peraturan Menteri Dalam Negeri Nomor 59. 2007. Perubahan atas Peraturan Menteri dalam Negeri Nomor 13 Tahun 2006 tentang Pedoman Pengelolaan Keuangan Daerah.

Peraturan Menteri Dalam Negeri Nomor 79. 2007. Pedoman Penyusunan Rencana Pencapaian Standar Pelayanan Minimal.

Peraturan Menteri Pendidikan Nasional Nomor 19.2007. Standar Pengelolaan Pendidikan oleh Satuan Pendidikan Dasar dan Menengah.

Peraturan Pemerintah Republik Indonesia Nomor 58. 2005. Pengelolaan Keuangan Daerah.

Peraturan Pemerintah Republik Indonesia Nomor 8.2006. Pelaporan Keuangan dan Kinerja Instansi Pemerintah.

Peraturan Pemerintah Republik Indonesia Nomor 20. 2004. Rencana Kerja Pemerintah. 
Peraturan Pemerintah Repiblik Indonesia Nomor 65.2005. Pedoman Penyusunan dan Penerapan Standar Pelayanan Minimal.

Peraturan Pemerintah Nomor 19. 2005. Sistem Pendidikan Nasional.

Piotrowski, Suzanne J., and David H. Rosenbloom. 2002. "Nonmission-Based Values in Results- Oriented Public Management: The Case of Freedom of Information." Public Administration Review 62.

Priyatno, Dwi. 2008. Mandiri Belajar SPSS Untuk Analisis Data dan Uji Statistik, Mediakom.

Rakhmat. 2005. Reformasi Admisitrasi Publik Menuju Pemerintahan Daerah yang Demokratis. Jurnal Administrasi Publik Vol.1, No.1.

Santoso. 2005. Pengaruh Komitmen Organisasi dan Gaya Kepemimpinan Terhadap Hubungan Antara Partisipasi Anggaran dan Kinerja Manajerial.SNA VIII. 15-16 September, Solo.

Schick. A. 1966, December, "The Road to PPB: The Stages of Budget Reform," Public Administration Review.

Sembiring, Binar Biak. 2009. Faktor-faktor yang Mempengaruhi Penyusunan Anggaran Pendapatan dan Belanja Daerah Berbasis Kinerja (Studi Empiris di Pemerintah Kabupaten Karo), Tesis, Medan

Sinaga, Obsatar. 2008. Kebijakan dan Agenda Reformasi Administrasi. Jurnal Administrasi Vol.1, No.4.

Solihin, Dadang. 2011. Penyusunan Anggaran Berbasis Kinerja. Bimbingan Teknis Perencana Bappeda Provinsi DKI Jakarta. Jakarta : Bappenas.

Stiefel, Leanna, Ross Rubenstein, and Amy Ellen Schwartz. 1999. "Using Adjusted Performance Measures for Evaluating Resource Use." Public Budgeting \& Finance 19.

Sugiono.2007. Metode Penelitian Administrasi dilengkapi dengan Metode R\&D,Edisi Revisi, Cetakan ke 16.Alfabeta, Bandung.

Sugiyanto.2004. Analisis Statistika Sosial.Bayumedia Publishing. Malang.

Sumarno. 2005. Pengaruh Komitmen Organisasi dan Gaya Kepemimpinan Terhadap Hubungan Antara Partisipasi Anggaran dan Kinerja Manajerial. SNA VIII. 15-16 September, Solo.

Vigoda, Eran. 2002. "From responsiveness to Collaboration: Governance, Citizens, and the Next Generation of Public Administration." Public Administration Review 62.

Wahono, Romi Satria. 2001. Pengantar Manajemen Organisasi, LIPI, Saitama University.

Wahyuningsih. 2009. Public Administration Community Reward and Punishment. Jakarta

Walters, J. .1994, April.The benchmarking craze.Governing, 7 (7).

Wibowo. 2007. Manajemen Kinerja. Jasa Grafindo, Jakarta.

Widiyantora. 2005.Pengaruh Gaya Kepemimpinan, Motivasi dan Komitmen Organisasi terhadap Kinerja Pegawai pada UPPD Kota Semarang.

Wildavsky, A. and Caiden, N. 1975. Planning and Budgeting in the Poor Countries, New York: John Wiley. 